Yana V. Fedko

\title{
COMPARATIVE ANALYSIS OF TRENDS IN THE DEVELOPMENT OF INDUSTRY DURING ECONOMIC TRANSFORMATION OF UKRAINE AND RUSSIA
}

$\mathrm{PhD}$ in Economics. Taras Shevchenko National University of Luhansk

1 Gogol Sq., Starobelsk, Lugansk region, 92703, Ukraine. yanakorotinal @ rambler.ru

\begin{abstract}
This article focuses on the identification of trends in the development of the industrial complex of Ukraine and Russia on the basis of the analysis of dynamics of the basic indicators of development of industry. The author reveals the dependence of GDP on the level of industrial development, the impact of investment and innovation at the level of industrial development.

Keywords: analysis; dynamics; performance; index of industrial production; industrial development; investment in fixed assets
\end{abstract}

\section{Федько Я.В.}

\section{СРАВНИТЕЛЬНЫЙ АНАЛИЗ ТЕНДЕНЦИЙ РАЗВИТИЯ ПРОМЫШЛЕННОСТИ В ПЕРИОД ЭКОНОМИЧЕСКИХ ТРАНСФОРМАЦИЙ УКРАИНЫ И РОССИИ}

кандидат экономических наук. Луганский национальный университет имени Тараса Шевченко пл. Гоголя, 1, г. Старобельск, Луганская обл., 92703, Украина. yanakorotinal@ rambler.ru

\begin{abstract}
Аннотация
Данная статья посвящена выявлению тенденций развития промышленного комплекса Украины и России на основе анализа динамики основных показателей развития промышленности. Выявлена зависимость уровня ВВП от уровня развития промышленности, влияние инвестиций и инноваций на уровень развития промышленного производства.
\end{abstract}

Ключевые слова: анализ, динамика, показатели, индекс промышленного производства, развитие промышленности, инвестиции в основной капитал.

Introduction. The industry is one of the leading branches in the structure of modern national economies of Ukraine and Russia. Industrial production has the strongest impact on economy of these countries. Many factors of financial well-being of the state, strong domestic and foreign policy depend on the growth or recession of industrial production.

Since 2012 in Ukrainian and Russian economy there comes a transitional stage of development for which the end of post-crisis restoration is common. In this transitional period, new strategic problems of social and economic development are formulated. The general task for national economies of both countries is creation of the new type economy having innovative reference point, adapted for processes of integration into the world economic space. There is a need for the directions and proportions change of the industry sector development. Namely: to strengthen its intensification, to increase competitiveness level, to rationalize the structure of production, to designate solutions of resource-saving and ecology problems.

During the post-crisis period of market transformations in Russia there were certain changes in the industry structure. The intensification of separate sub-sectors development in the industry structure is various. It is connected with features of their formation, establishment of inter-industry ratios and proportions, extent of scientific and technical progress introduction. In structure of the Ukraine and Russia industry the share of extracting branch unlike world tendencies which is guided by the demand formed in a foreign market prevails.

The current state of the Ukraine and Russia industry is defined by adverse macroeconomic factors of influence, symptoms of economic crises 
and political conflicts manifestation. Research of the industry condition of Russia and Ukraine is directed on identification of cause and effect relationships, factors of the external and internal environment, as well as analysis of the main indicators of the industrial enterprises activity. Among which amount of investments, share of innovations, industrial output, quantity of employed that gives the chance to reveal tendencies and regularities of the industrial enterprises development, and also to predict further development of the industry in these countries. Results of the carried-out analysis can form base for adoption of reasonable administrative decisions and formulation of the industrial policy directions for the purpose of competitiveness increase for industrial output domestic producers.
Main Part. Estimation of development for any branch of national economy including the industries, the analysis of various factors assumes the following: production, economic and social factors [7].

First of all it is necessary to define a share of industry in GDP and to analyze tendencies of its change.

In 2014 the share of the industry in structure of Ukraine GDP makes about $25 \%$ and about $35 \%$ - in GDP of Russia. And every year this share is reduced. First of all, it resulted from changes of price proportions on production of mining branches. During post-crisis recovery of national economies in Ukraine and Russia reduction of GDP (fig. 1) is observed.

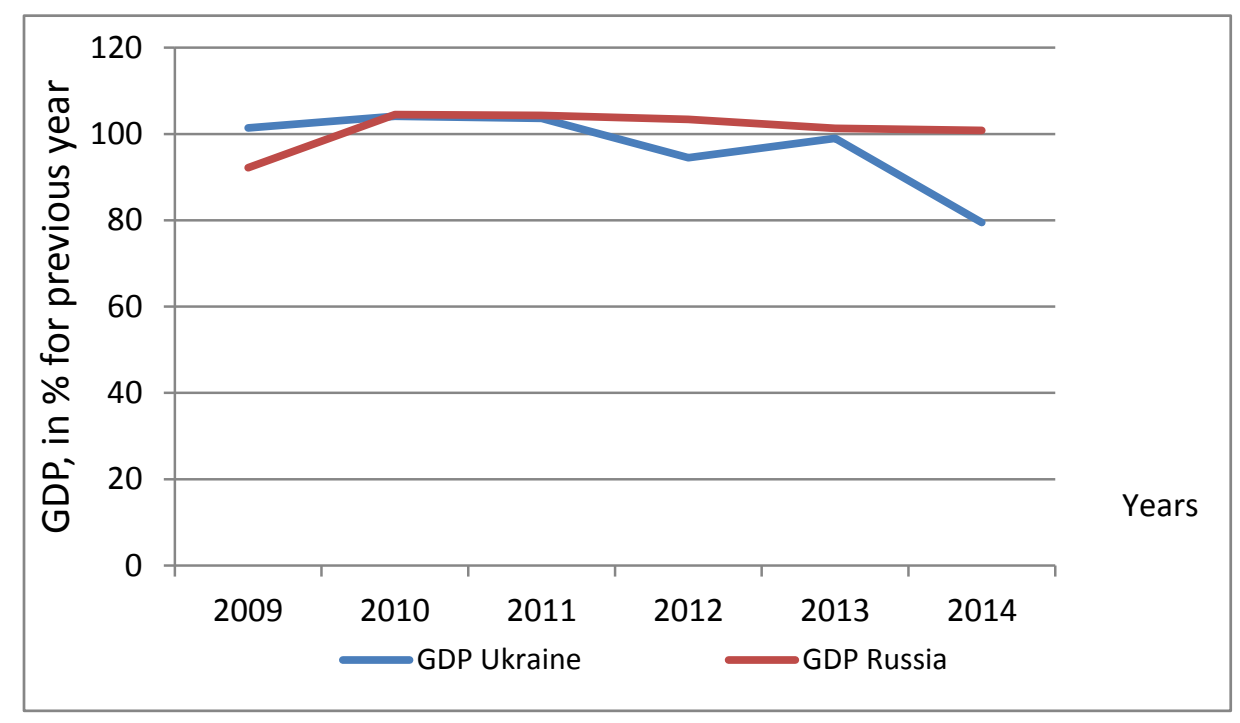

Fig. 1. Dynamics of the GDP of Ukraine and Russia in 2009-2014 (\% to the previous year) Puc. 1. Динамика ВВП Украины и России за 2009-2014 гг. ( в \% к предыдущему году)

In fig. 1 it is visible that for 2009-2014 GDP of Ukraine reaches the maximum value in 2011 and makes $105.5 \%$. In 2012 sharp reduction of GDP which in 2014 reaches value of $93.2 \%$ that is $8.2 \%$ lower than GDP in 2009 is observed [9, p. 66 ]. GDP of Russia reaches its maximum in 2010 (104.5\%), and, since 2011, gradually decreases. However, GDP of Russia in 2014 exceeds a similar indicator of 2009 for 8.6\% [10, 11]. In 2014 it occurs, first of all, due to reduction of financial receipts from the industrial enterprises caused by political instability in these countries. Sharp falling of GDP in Ukraine is caused by that the majority of the large industrial enterprises in the territory of Donetsk and Lugansk areas were minimized, or completely suspended their activity.

Efficiency of industrial policy realization depends on condition of the industry investment. In particular, business activity of the industrial enterprises, their productivity and efficiency directly proportionally depend on the volume of investment into fixed capital (fig. 2.). 


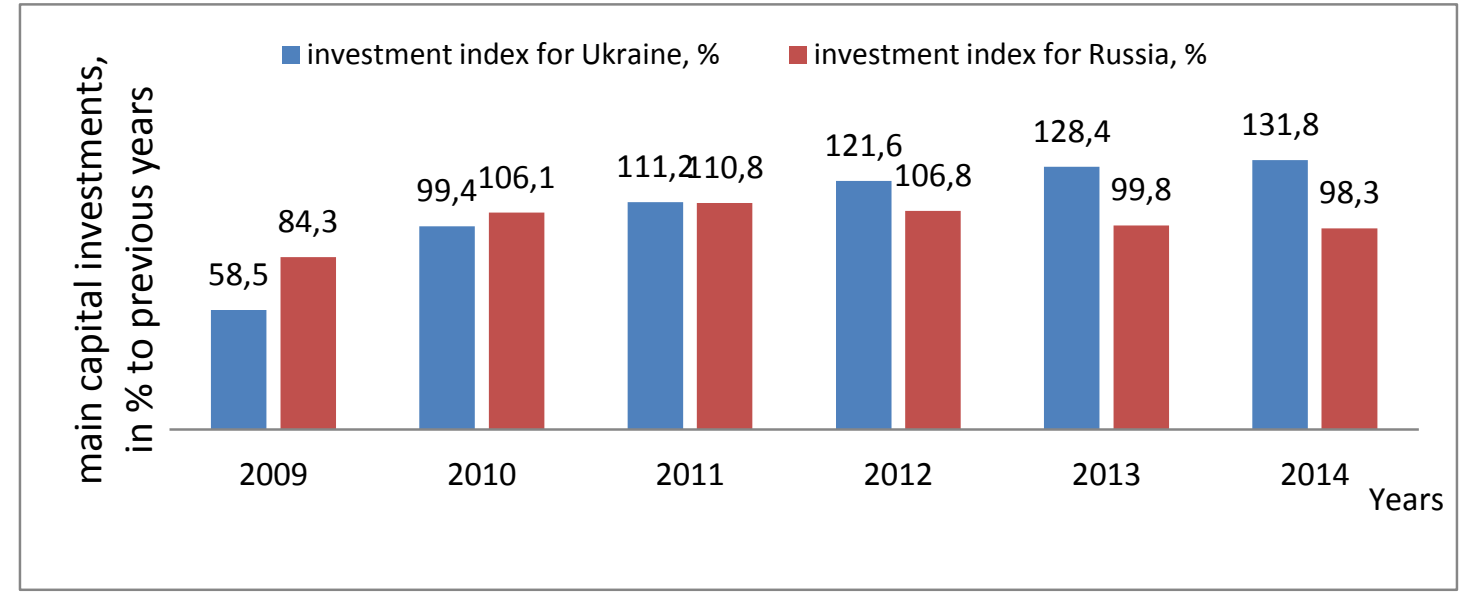

Fig. 2. Dynamics of investment in fixed assets in Ukraine and Russia in 2009-2014 (\% to the previous year)

Puc. 2. Динамика инвестиций в основной капитал Украины и России за 2009- 2014 гг. (в \% к предыдущему году)

Dynamics of the industry investments change in general, and by separate types of economic activity is subject to extreme dependence with peak in 2014 in Ukraine (131.8\%) and 2011 in Russia $(110.8 \%)$ [1, p. 53, 2, p. 46, 6].

The public policy in Ukraine and Russia which is carried out for years of transformations did not promote increase of innovative activity though experience of other countries, including a number of Eastern Europe countries, testifies that a common sign of transition period is sharp strengthening of innovative activity. Let us provide some data characterizing development of innovative activity in Ukraine for years of reforming [4].

Introduction of new progressive engineering procedures for years of reforms was reduced almost by 5 times, including resource-saving, lowwaste and waste-free technologies - by 3 times, development of new types of production - by 1.9 times, of them new types of equipment - by 16.2 times and made the smallest share in the total amount of development for innovative production - only $8.5 \%$ in 2013 whereas in 1996 this indicator made $83 \%$ [1, p. 51, 2, p. 43].

For the innovation-active enterprises greater demand on products which is delivered not only on domestic market, but also on the external is common. So, in general on selection, the foreign market is entered by about $60 \%$ of the industrial enterprises of the processing branches, among the innovation-active industrial enterprises - more than $70 \%$.

Increase in demand for industrial output of the Ukrainian enterprises in a foreign market, in general on selection, is noted at $9 \%$, at the innovation-active enterprises this indicator is higher $-18 \%$ of the organizations.

The number of the enterprises in Ukraine introducing innovations in 2009 in comparison with 1996 was reduced by 1.8 times. Since 2009 revival of innovative activity of the industrial enterprises (fig. 3) begins. 


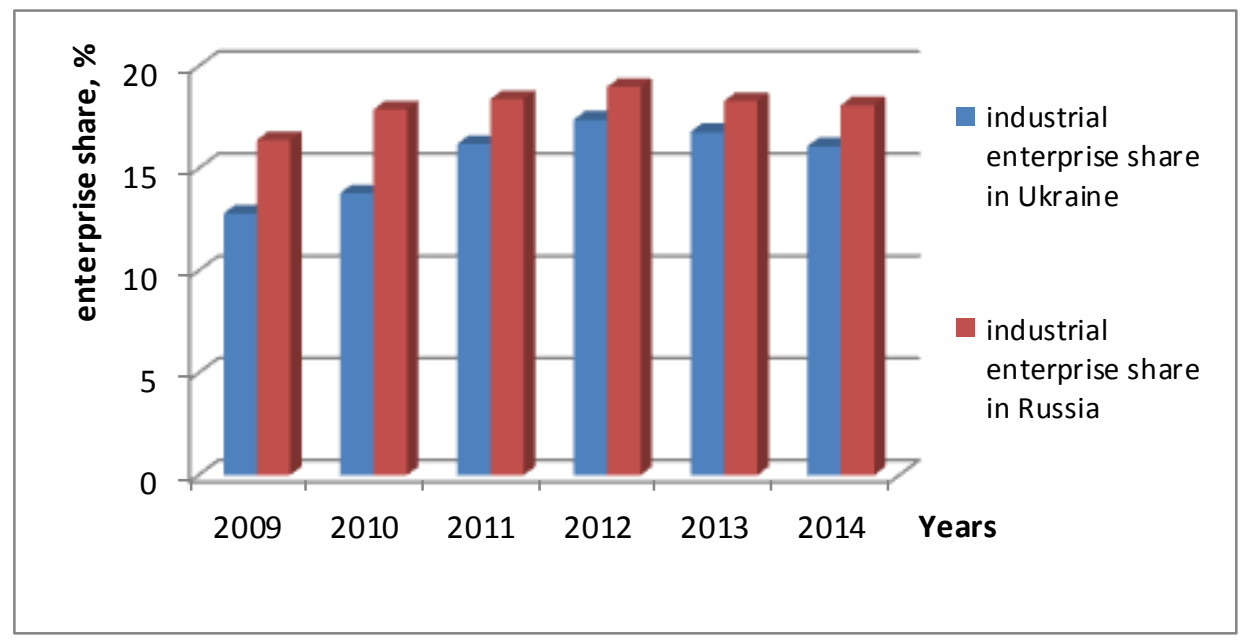

Fig. 3. The dynamics of the industrial enterprises of Ukraine and Russia, which were engaged in innovation in 2009-2014 (\% to the total number of industrial enterprises)

Puc. 3. Динамика доли промышленных предприятий Украины и России, которые занимались инновациями за 2009-2014 гг. (в \% к общему количеству промышленных предприятий)

For the beginning of 2014 in comparison with the beginning of 2009, despite sharp falling GDP and political instability, their share in the total number of the industrial enterprises increased for $3.3 \%$ and made $16.1 \%$.

The greatest share of innovative expenses in the industry $(40 \%)$ is connected with acquisition of new machines, equipment and installations necessary for production technological updating. More than average on set of the surveyed enterprises funds were spent for purchasing the equipment in forest, woodworking and pulp and paper industry - 55\% of total number of the organizations which are carrying out the innovation for light industry (50\% of the enterprises).

On research and construction work 16\%-18\% of all costs of innovations are necessary. Above average on branch, is the share of research and development costs in light industry (24\%), mechanical engineering and metal working (18\%). The fifth part of expenses (21\%) goes to the enterprises for innovations development and introduction.

There is low share of market researches costs for the innovation market, and also on legal protection of research and development (6\% of the organizations) $[1$, p. 51,2, p. 43$]$.

In Russia throughout all studied period the share of the industrial enterprises gradually increases, reaching the greatest value in 2012 (19\%) [6]. For the next two years the share of the Russian industrial enterprises which are engaged in innovations is reduced to $18.1 \%$, whereas in the USA, Japan, Germany and France their share makes 70-80\% [5].

One of the important indicators of the industry development is the index of industrial production, or an index of industrial output production, or the index of an industrial output (IIO) - a relative indicator of industrial production output dynamics which characterizes its rise or recession. The index of industrial production is defined as a ratio of the current output (in terms of money) to industrial outputs in the previous periods. The methodology of IIO calculation is based on use of statistical data on dynamics of production types according to a certain set of goods representatives - the most important types of industrial output.

Dynamics of industrial production index in Ukraine from January, 2011 to September, 2015 (against the last month) is presented in table 1.

Table 1

Dynamics of indexes of industrial production in Ukraine from 2011 to 2015

Таблица 1

Динамика индексов промышленного производства в Украине с 2011 по 2015 годы

\begin{tabular}{|c|c|c|c|c|c|c|c|c|c|c|c|c|c|}
\hline 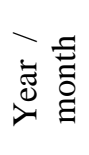 & 㲵 & 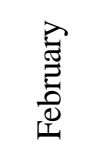 & 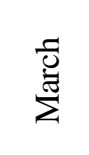 & 离 & $\sum^{\vec{\epsilon}}$ & $\Xi$ & 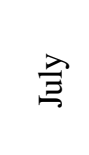 & 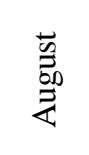 & 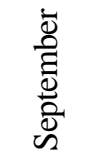 & 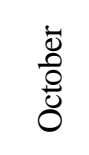 & $\begin{array}{l}\dot{\bar{d}} \\
\bar{\Xi} \\
\overrightarrow{0} \\
z\end{array}$ & 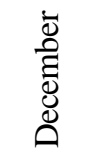 & 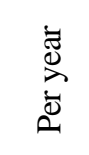 \\
\hline 2011 & 87.2 & 101.2 & 113.2 & 94.6 & 100.3 & 100.8 & 102.7 & 101.7 & 102.0 & 105.2 & 97.0 & 99.7 & 103.6 \\
\hline 2012 & 86.2 & 101.9 & 110.2 & 95.6 & 101.9 & 98.0 & 104.3 & 98.1 & 100.0 & 106.8 & 97.4 & 96.1 & 94.5 \\
\hline 2013 & 88.9 & 99.4 & 111.0 & 98.5 & $\begin{array}{l}94.4 \\
\end{array}$ & 101.6 & 105.1 & 97.5 & 99.6 & 107.4 & 97.4 & 100.1 & 99.0 \\
\hline 2014 & 84.0 & 100.3 & 107.4 & 98.4 & 98.3 & 98.5 & 97.8 & 87.3 & 104.9 & 107.5 & $\begin{array}{l}97.8 \\
\end{array}$ & 7.9 & 79.5 \\
\hline 2015 & 80.3 & 98.4 & 109.6 & 98.0 & $\begin{array}{c}99.8 \\
\end{array}$ & 101.5 & 103.4 & 95.8 & 105.9 & & & & \\
\hline
\end{tabular}


From table 1 it is visible that at preservation of the existing dynamics by the end of 2015 in Ukraine IIO will reach $90 \%$

The increase in IIO in 2015 occurs at the expense of increase in IIO of industrial areas. So, IIO in the Dnepropetrovsk area for the last half a year increased by $2.2 \%[10]$.

Growth of IIO in the Kharkov area is explained by a growth in volumes of production and sales volumes of the industrial enterprises of the defensive direction in 2014-2015. So, GP "Plant of V.A. Malyshev" volumes of product sales increased by $144.5 \%$ that in terms of money makes 11 million
UAH, GP "Kharkov Plant of Special Machines" 128.84\% (10 million UAH), GP "Kharkov Mechanical Plant" - 662.9\% (656 thousand UAH). In general on area, in 2014 in comparison with previous year industrial output on 9.5 billion is made and realized [1].

In Russia IIO is calculated according to Official statistical methodology of industrial production index calculation [8]. In Ukraine it is done by the similar technique accepted in the international statistics. The IIO loudspeaker in Ukraine and Russia for 2006-2014 it is presented in fig. 4.

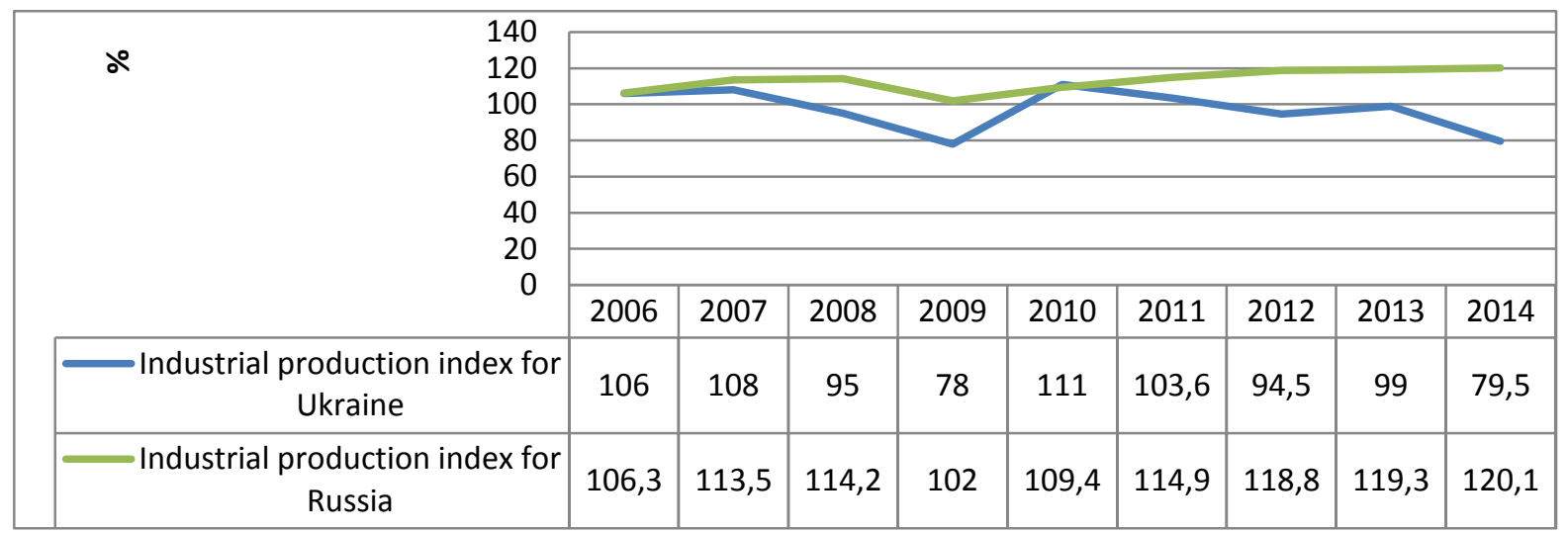

Fig. 4. Dynamics of the index of industrial production in Ukraine and Russia in 2006-2014 (\% to the previous year) Puc. 4. Динамика индекса промышленной продукции Украины и России за 2006-2014 гг. ( в \% к предыдущему году)

Since 2009 for the Russian producers of industrial output growth of industrial production index to the level of $120.1 \%$ is common (in 2014) it shows a positive tendency of development of the Russian industry and increase of competitiveness level for industrial production on international level.
Employment of the population in the industry characterizes extent of the industry development in the general structure of national economy branches.

Population, occupied in industrial production of Russia, during the period from 2006 to 2014 had a steady tendency to reduction (for 14.1\%) (fig. 5).

\begin{tabular}{|c|c|c|c|c|c|c|c|c|c|c|}
\hline \multirow{7}{*}{ dீ } & \multicolumn{10}{|l|}{120,00} \\
\hline & \multicolumn{10}{|l|}{100,00} \\
\hline & \multicolumn{10}{|l|}{80,00} \\
\hline & \multicolumn{10}{|l|}{60,00} \\
\hline & \multirow{2}{*}{\multicolumn{10}{|c|}{20,00}} \\
\hline & & & & & & & & & & \\
\hline & & 2006 & 2007 & 2008 & 2009 & 2010 & 2011 & 2012 & 2013 & 2014 \\
\hline \multicolumn{2}{|c|}{$\begin{array}{c}\text { Industrial production index for } \\
\text { Ukraine }\end{array}$} & 39,80 & 40,30 & 39,30 & 38,50 & 36,80 & 38,9 & 39,1 & 39,4 & 39,5 \\
\hline \multicolumn{2}{|c|}{$\begin{array}{c}\text { Industrial production index for } \\
\text { Russia }\end{array}$} & 97,7 & 97,7 & 96,5 & 88 & 85,5 & 85,3 & 84,1 & 83,3 & 83,1 \\
\hline
\end{tabular}

Fig. 5. Dynamics of the number of employees in industrial production in Ukraine and Russia in 2006-2014 (in\% to previous year) Puc. 5. Динамика численности занятых в промышленном производстве Украины и России за 2006-2014 гг. ( в \% к предыдущему году)

Even thus that total number occupied in national economy throughout the considered period annually was reduced, the share occupied in industrial complex to total number occupied in economy of Russia decreased [11]. In 2009 the share of the population occupied in the industry was reduced by 
8.5\% in comparison with 2008 and made $88 \%$ [1, p. 63,2, p. 57].

In comparison with changes of quantity occupied at the industrial enterprises of the Russian Federation, the level of employment in the industry of Ukraine throughout the studied period can be considered stable. For the last 8 years the quantity occupied in the industry of Ukraine was reduced only by $0.3 \%$ (fig. 5). Reductions of employment level in the industry as well as its stability, depends, first of all, on extent of NTP introduction.

Results. By results of the carried-out dynamics analysis of the main development indicators for the industry of Ukraine and Russia during post-crisis restoration the following tendencies are revealed:

1. reduction of GDP for both countries;

2. increase in investments into fixed capital of Ukraine (to $131.8 \%$ in 2014) reduction for Russia (to 98.3\%);

3. reduction of the industrial enterprises in Ukraine (to $16.1 \%$ in 2014) and Russia (to 18.1\%) which were engaged in innovations;

4. growth of industrial output index in Russia (120.1\%) and achievement of critically low value for Ukraine (79.5\%);

5. reduction of number occupied in industrial production of Russia and stability of this indicator for Ukraine.

Conclusion. Considering the share of industry in structure of GDP that in Ukraine makes about 25\% and about 35\% - in Russia, it is necessary to set the priority purposes of economic policy the industries aimed at the development in these countries.

For Russia growth of IIO signifies increase in production that is expressed in profit increase of the industrial enterprises at the expense of which implementation of their investment and innovative activity becomes possible is common.

Reduction of IIO in Ukraine for 2013 - 2014 is caused by impossibility of many industrial enterprises functioning due to being situated in a conflict zone in the territory of Luhansk and Donetsk region. And also reduction of production prices for the industrial enterprises in the world market [5].

During innovative policy, it is necessary to estimate efficiency of innovations. For the industrial enterprises of Ukraine there are factors constraining carrying out innovative policy. Among which insufficiency of own means of financing, unprofitable credit conditions, long lag period for innovations, high risk of innovations introduction [4].

In the world market production of the industrial enterprises of Ukraine and Russia has the low level of competitiveness. Introduction of innovations promotes increase of level of their competitiveness not only on internal, but also in the foreign market.

For achievement of this purpose during postcrisis restoration it is expedient to intensify restructuring processes that has to lead to financial improvement of the industrial enterprises and increase of their investment appeal degree.

On purpose elimination of the existing crisis consequences of national economy it is necessary to formulate the respective directions of evidence-based public policy. Such policy has to be based on results of the carried-out analysis taking into account adaptation to features of national economy. Besides, it has to be focused on formation of the new directions for national economies recovery from influence of negative consequences of world financial and economic crisis. When forming the new directions of public policy on restoration of the industry during the post-crisis period it is necessary to consider current trends of industrial production development on the international level.

\section{References}

1. Activities of Subjects of Economy Management. Statistical Dijest. State statistics service of Ukraine, Kiev, 2009. 424 p.

2. Activities of Subjects of Economy Management. Statistical Dijest. State statistical service of Ukraine, Kiev, 2013. 447 p.

3. Chief Department of Statistics in Kharkov Region. URL: http://uprstat.kharkov.ukrtel.net

4. Deyneko, L.V. Trade of Ukraine with the Countries of the Customs Union: Contemporary Tendencies and Risks for the National Industrial Production / L.V. Deyneko // Economy of Ukraine. № 8. 2015. Pp.74-90.

5. Eurostate.

URL: http:

//ec.europa.eu/eurostat/help/new-eurostat-website

6. Federal State Statistics Service. Industry of Russia 2014. URL: http://www.gks.ru/bgd/regl/b14_48/Main.htm

7. Fedko, Y. The Basic Principles of the Systematic Approach for Estimating the Efficiency of the Industrial Production in the Region / Y.V. Fedko // International Scientific Publication "Modern basic and applied research." №3 (18). Kislovodsk: PH EC "MAGISTR", 2015. Pp.73 - 76.

8. Order of the Federal State Statistics Service on May 8, 2014 N 301 «On Approval of the official statistical methodology for calculating the index of industrial Production».

URL:

http://base.consultant.ru/cons/cgi/online. cgi? base = LAW; frame $=1$

9. The Ministry of Finance of the Russian Federation. Macroeconomics. / URL: http://info.minfin.ru/gdp.php

10. The Ministry of Finance of Ukraine. Financial Portal. URL: http://www.minfin.com.ua/index/prom/

11. Ukraine in Figures. Statistical Dijest. State

Statistics Committee of Ukraine, Kiev, 2011. 252 p. 